\title{
Model Guided Inquiry Berbasis Scientific Approach dalam Pembelajaran IPA Biologi Siswa SMP N 14 Yogyakarta
}

\author{
Siti Madiniah, Dian Noviar
}

Pendidikan Biologi, Fakultas Sains dan Teknologi

UIN Sunan Kalijaga Yogyakarta

surat elektronik: diannoviar84@yahoo.co.id

\begin{abstract}
ABSTRAK
Implementasi pembelajaran IPA Biologi di SMP masih sebatas penyampaian materi oleh guru dan penekanan penguasaan materi (kognitif) terhadap siswa. Penggunaan model Direct Instruction yang masih mendominasi di kelas kurang memberikan kesempatan kepada siswa untuk terlibat langsung dalam pembelajaran sehingga berdampak pada hasil belajar yang belum maksimal. Penelitian ini bertujuan untuk mengetahui hasil belajar IPA Biologi siswa kelas VII pada aspek kognitif, afektif, dan psikomotor ditinjau dari penerapan Model Guided Inquiry berbasis Scientific Approach. Penelitian ini termasuk penelitian quasy experiment dengan desain nonequivalent control group design. Populasi penelitian adalah semua siswa kelas VII SMP N I4 Yogyakarta T.A. 20I4/20I5. Sampel penelitian terdiri dari dua kelas yang diambil dengan teknik purposive sampling, yaitu kelas VII A (kelas eksperimen) dan kelas VII B (kelas kontrol). Teknik pengumpulan data menggunakan tes, angket, dan observasi. Analisis data hasil belajar siswa pada aspek kognitif menggunakan Independent Samples t-test, aspek afektif dan psikomotor menggunakan uji Mann Whitney U Test. Hasil belajar IPA Biologi pada kelas kontrol dan kelas eksperimen signifikan rata-rata berbeda untuk aspek kognitif, afektif, dan psikomotor ditunjukkan dengan $\mathrm{p}<0,05$. Dengan demikian, dapat disimpulkan bahwa hasil belajar IPA Biologi pada aspek kognitif, afektif, dan psikomotor signifikan rata-rata berbeda ditinjau dari penerapan Model Guided Inquiry berbasis Scientific Approach.
\end{abstract}

Kata kunci: Guided Inquiry, Scientific Approach, Pembelajaran, Hasil Belajar

\section{Pendahuluan}

Tanpa disadari, kurikulum di Indonesia telah mengalami beberapa kali pergantian. Pergantian tersebut didasarkan atas kebutuhan, peningkatan proses belajar mengajar, dan tuntutan zaman. Merujuk pada standar proses kurikulum 2006 yang saat ini di terapkan, terdapat beberapa perubahan paradigma pembelajaran. Interaksi pembelajaran yang awalnya menekankan guru sebagai pusat belajar (teacher centered), kemudian beralih menjadi siswa yang belajar, dan menemukan sendiri (student centered). Hal tersebut, menuntut peran guru dalam mengkonsep proses belajar sehingga siswa turut aktif dan menyediakan pengalaman belajar yang bermakna.

Menurut Daryanto (2005: 58), pada dasarnya tujuan pembelajaran adalah tujuan yang menggambarkan pengetahuan, kemampuan, keterampilan, dan sikap. Kesemuanya harus dimiliki siswa sebagai akibat dari hasil pembelajaran yang dinyatakan dalam bentuk tingkah laku yang diamati dan diukur. Dalam proses pembelajaran, tugas dan peran guru tidak hanya memberi informasi, tetapi dapat menyediakan suasana belajar yang mampu mendorong siswa untuk dapat aktif dalam mengkonstruksi pengetahuan dalam pikirannya sendiri.

Seperti halnya dalam pembelajaran Ilmu Pengetahuan Alam (IPA) di tingkat sekolah menengah pertama, siswa dituntut mampu untuk mengkonstruksi konsep-konsep pengetahuannya sendiri, sehingga tercipta implementasi pembelajaran dengan konsep student centered. Menurut Badan Standar Nasional Pendidikan (2006: 45I), dalam kurikulum KTSP biologi berkedudukan sebagai salah satu mata pelajaran dalam Ilmu Pengetahuan Alam yang menyediakan berbagai pengalaman belajar untuk memahami konsep dan proses sains. Penerapan pembelajaran student centered yang menuntut peran aktif siswa sangat dianjurkan dalam pembelajaran, sehingga apa yang dipelajari oleh siswa dapat dipahami, diaplikasikan, bahkan dapat dievaluasi.

Pembelajaran IPA Biologi di sekolah tidak akan lepas dari berbagai kendala dan permasalahan yang ada. Permasalahan yang muncul berkaitan dengan proses pembelajaran IPA Biologi di sekolah-sekolah ialah masih rendahnya hasil belajar siswa pada mata pelajaran tersebut. Berdasarkan hasil observasi di SMP N I4 
Yogyakarta pada semester gasal Tahun Ajaran 20I4/20I5, menunjukkan bahwa proses pembelajaran IPA Biologi masih terpusat pada guru (teacher centered). Model pembelajaran direct instruction yang digunakan guru masih mendominasi. Hal itu dikarenakan keterbatasan waktu yang dimiliki guru jika harus mengkonsep model pembelajaran baru mengingat banyaknya target materi yang perlu diselesaikan.

Kondisi tersebut menyebabkan siswa terlihat bosan dalam mengikuti pembelajaran sehingga berdampak pada hasil belajar yang tidak maksimal yang diperoleh siswa, salah satunya pada materi pokok ekosistem. Data tersebut dibuktikan dengan hasil ulangan harian siswa pada materi ekosistem pada tahun ajaran sebelumnya, yaitu Tahun Ajaran 2013/20I4 dengan rata-rata nilai sebesar 68. Nilai tersebut masih dibawah KKM 71,25. Media pembelajaran yang digunakan guru baru sebatas power point sehingga menjadikan siswa kurang termotivasi dalam pembelajaran IPA Biologi. Dalam proses belajar, guru belum mempertimbangkan gaya belajar yang dimiliki siswa, dimana hasil survei pada 25 siswa dari 34 siswa yang menjadi responden di kelas VII A menunjukkan bahwa 3I,4\% siswa memiliki gaya belajar kinestetik, I4,2 \% gaya belajar audio dan 25,7\% gaya belajar visual.

Berdasarkan permasalahan tersebut, diperlukan sebuah inovasi penerapan model pembelajaran yang efektif sesuai dengan karakteristik materi dan karakteristik siswa di kelas sehingga mampu meningkatkan hasil belajar IPA Biologi siswa. Model pembelajaran yang dapat diterapkan adalah model Guided Inquiry. Model pembelajaran Guided Inquiry merupakan model pembelajaran inkuiri yang dalam pelaksanaannya guru menyediakan bimbingan atau petunjuk yang cukup luas kepada siswa. Sebagian perencanaan dibuat oleh guru, siswa tidak merumuskan masalah. Dalam pembelajaran inkuiri terbimbing guru tidak melepas begitu saja kegiatan-kegiatan yang dilakukan oleh siswa. Model Guided Inquiry adalah rangkaian pembelajaran yang menekankan proses berfikir secara kritis dan analitis untuk mencari dan menemukan sendiri jawaban dari suatu masalah yang dipertanyakan (Mulyasa, 2006: I08).

Tujuan utama Guided Inquiry atau inkuiri terbimbing adalah untuk mengembangkan siswa yang mandiri yang tahu bagaimana memperluas pengetahuan dan keahlian melalui penggunaan keahlian dari berbagai sumber informasi yang digunakan baik di dalam maupun di luar sekolah. Sumber daya di dalam sekolah seperti bahan pustaka, database, dan sumber-sumber yang dipilih lainnya (Hamalik, 200I: I88).

Selain penggunaan model pembelajaran, untuk dapat melibatkan siswa aktif dalam proses belajar mengajar di kelas dan mampu meningkatkan retensi siswa, diperlukan pula suatu pendekatan pembelajaran (Lubis, 2010: I87-I88). Salah satu pendekatan pembelajaran yang tepat digunakan dalam model pembelajaran Guided Inquiry adalah pendekatan saintifik (scientific approach).

Pendekatan saintifik (scientific approach) merupakan pendekatan pembelajaran yang berorientasi atau berpusat pada siswa (student centered approach). Pendekatan saintifik dirancang sedemikian rupa sehingga siswa secara aktif mampu mengkonstruk konsep, hukum, atau prinsip melalui tahapan-tahapan mengamati, menanya, mencoba, mengolah data, menyajikan dan mengkomunikasikan. Pendekatan ini dimaksudkan untuk memberikan pemahaman kepada siswa dalam mengenal dan memahami berbagai materi menggunakan pendekatan ilmiah sehingga perolehan informasi tidak hanya dari guru melainkan penemuan siswa sendiri. Pendekatan scientific memiliki karakteristik "doing science", sehingga memudahkan guru atau pengembang kurikulum untuk memperbaiki proses pembelajaran, yaitu dengan memecah proses ke dalam langkah-langkah atau tahapan-tahapan secara terperinci yang memuat instruksi untuk siswa melaksanakan kegiatan pembelajaran (Varelas, 2008: 3I).

Pembelajaran IPA biologi pada materi ekosistem memposisikan siswa sebagai pebelajar, yaitu subjek yang belajar. Siswa harus mampu mengkonstruk pengetahuan dan konsep dengan belajar secara kontekstual. Hal ini sangat penting sebab dengan mengkorelasikan materi dengan kehidupan nyata, materi yang dipelajari akan tertanam erat dalam memori siswa sehingga tidak akan mudah terlupakan. Pembelajaran materi ekosistem dengan model Guided Inquiry berbasis Scientific Approach ini diharapkan mampu meningkatkan hasil belajar IPA Biologi baik pada aspek kognitif, aspek afektif, dan aspek psikomotor siswa.

Hasil penelitian penelitian oleh Sagung Putri, dkk (20I4) menyatakan bahwa implementasi metode inkuiri terbimbing ditinjau dari sikap ilmiah siswa dapat meningkatkan hasil belajar IPA Biologi kelas VII SMP N Tegalalang. Selain itu, penelitian yang dilakukan oleh Marjan (20I4), menunjukkan bahwa pembelajaran dengan pendekatan saintifik meningkatkan keterampilan proses sains, hal ini dikarenakan siswa melakukan pengamatan langsung pada objek yang diamati sebagai dasar yang dilakukan oleh para ilmuwan. Berdasarkan uraian yang telah dikemukakan di atas, maka penulis tertarik untuk melakukan penelitian dengan judul penelitian "Model Guided Inquiry Berbasis Scientific Approach dalam Pembelajaran IPA Biologi Siswa SMP N I4 Yogyakarta”. Adapun tujuan penelitian ini adalah untuk mengetahui hasil belajar IPA Biologi siswa kelas VII pada aspek kognitif, afektif, dan psikomotor ditinjau dari penerapan Model Guided Inquiry berbasis Scientific Approach.

\section{Metode Penelitian}

Sampel penelitian terdiri dari dua kelas di SMP N I4 Yogyakarta yaitu kelas VII A dan Kelas VII B yang diambil secara purposive sampling. Kelas VII A sebagai kelas eksperimen dengan pemberian perlakuan menggunakan Model 
Guided Inquiry berbasis Scientific Approah, dan kelas VII B sebagai kelas kontrol menggunakan Model Direct Instruction. Instrumen yang digunakan terdiri atas instrumen perangkat pembelajaran dan instrumen penelitian. Teknik analisis data terdiri atas uji prasyarat analisis dan uji analisis hipotesis.

Uji prasyarat analisis dilakukan sebagai persyaratan sebelum melakukan uji hipotesis dimana data harus berdistribusi normal dan homogen varians. Uji analisis hipotesis untuk data hasil belajar aspek kognitif menggunakan Independent Samples t-Test, sedangkan untuk data hasil belajar aspek afektif dan psikomotor menggunakan uji Mann Whitney $U$ Test. Uji statistik dilakukan pada taraf signitifansi 5\%.

\section{Hasil dan Pembahasan}

Data dalam penelitian ini meliputi data hasil belajar aspek kognitif, afektif, psikomotor, serta tanggapan siswa terhadap penggunaan Model Guided Inquiry berbasis Scientific Approach. Data tersebut diperoleh dari hasil tes, angket, dan observasi siswa kelas VII A dan Kelas VII B yang berjumlah masing-masing 34 siswa. Pada penelitian ini, kelas VII A sebagai kelas eksperimen dan kelas VII B sebagai kelas kontrol. Berdasarkan penelitian yang telah dilakukan di SMP N I4 Yogyakarta diperoleh hasil sebagai berikut:

Tabel I. Deskripsi Data Nilai Hasil Belajar Aspek Kognitif Siswa

\begin{tabular}{lllll}
\hline Kelas & $\begin{array}{l}\text { Jumlah } \\
\text { Siswa }\end{array}$ & Mean & Maks & Min \\
\hline Kontrol & 34 & 74,12 & 90 & 65 \\
Eksperimen & 34 & 81,18 & 95 & 70 \\
\hline
\end{tabular}

Berdasarkan Tabel I, dapat disimpulkan bahwa rata-rata nilai hasil belajar aspek kognitif siswa kelas eksperimen lebih tinggi daripada kelas kontrol.

Tabel 2. Distribusi Kategori Nilai Aspek Kognitif Siswa

\begin{tabular}{ccccc}
\hline Kategori & \multicolumn{3}{c}{ Kelas Kontrol } & \multicolumn{3}{c}{ Kelas } \\
& \multicolumn{4}{c}{ Eksperimen } \\
\cline { 2 - 5 } & N & $\begin{array}{c}\text { Persentas } \\
\text { e (\%) }\end{array}$ & N & $\begin{array}{c}\text { Persentas } \\
\text { e (\%) }\end{array}$ \\
\hline Sangat Baik & I0 & 29 & 23 & 68 \\
Baik & I7 & 50 & I I & 32 \\
Cukup & 7 & 21 & 0 & 0 \\
Kurang & 0 & 0 & 0 & 0 \\
Sangat Kurang & 0 & 0 & 0 & 0 \\
Jumlah & 34 & I00 & 34 & 100 \\
\hline
\end{tabular}

Berdasarkan Tabel 2, pada kelas kontrol terdapat 29\% siswa yang memiliki kategori sangat baik dan $68 \%$ siswa pada kelas eksperimen yang memiliki nilai dengan kategori sangat baik. Dapat disimpulkan bahwa nilai siswa kelas eksperimen lebih tinggi daripada kelas kontrol.

Tabel 3. Deskripsi Data Nilai Hasil Belajar Aspek Afektif

\begin{tabular}{lllll}
\hline Kelas & $\begin{array}{l}\text { Jumlah } \\
\text { Siswa }\end{array}$ & Mean & Maks & Min \\
\hline Kontrol & 34 & 75,59 & 86 & 62 \\
Eksperimen & 34 & 78,09 & 92 & 64
\end{tabular}

Berdasarkan Tabel 3, dapat disimpulkan bahwa nilai rata-rata aspek afektif siswa kelas eksperimen lebih tinggi dibandingkan kelas kontrol.

Tabel 4. Deskripsi Data Nilai Hasil Belajar Aspek Psikomotor

\begin{tabular}{lllll}
\hline Kelas & $\begin{array}{l}\text { Jumlah } \\
\text { Siswa }\end{array}$ & Mean & Maks & Min \\
\hline Kontrol & 34 & 42,09 & 48 & 33 \\
Eksperimen & 34 & 50,59 & 59 & $4 \mathrm{I}$ \\
\hline
\end{tabular}

Berdasarkan Tabel 4, dapat disimpulkan bahwa nilai rata-rata hasil belajar aspek psikomotor siswa kelas eksperimen lebih tinggi dibandingkan kelas kontrol sehingga dapat disimpulkan bahwa terdapat perbedaan yang signifikan pada kedua kelas tersebut.

Untuk uji hipotesis data hasil belajar aspek kognitif menggunakan Independent Samples t-Test, sedangkan untuk data hasil belajar aspek afektif dan psikomotor menggunakan uji Mann Whitney U Test. Pengujian hipotesis menggunakan SPSS for Windows 16.0. Uji statistik dilakukan pada taraf signifikansi 5\%. Jika $p$-value $<0,05$, maka $H_{0}$ ditolak yang berarti terdapat perbedaan, sedangkan jika $p$-value $>0,05$ maka $\mathrm{H}_{0}$ diterima yang berarti tidak terdapat perbedaan. Ringkasan hasil uji hipotesis dapat dilihat pada Tabel 5.

Tabel 5. Hasil Uji Hipotesis Hasil Belajar Aspek Kognitif, Afektif, dan Psikomotor

\begin{tabular}{ccc}
\hline Hipotesis & Hasil Belajar & Sig. \\
\hline I & Kognitif & 0,000 \\
\hline & Gains Score Kognitif & 0,012 \\
\hline $\mathbf{2}$ & Afektif & 0,037 \\
& Psikomotor & 0,000
\end{tabular}


Berdasarkan Tabel 6, dapat disimpulkan pengujian hipotesis pada aspek kognitif, afektif, dan psikomotor serta tanggapan siswa terhadap penggunaan Model Guided Inquiry Berbasis Scientific Approach sebagai berikut:

\section{Hasil Belajar Pada Aspek Kognitif}

Berdasarkan uji hipotesis, didapatkan bahwa $\mathrm{H}_{0}$ ditolak, artinya Model Guided Inquiry berbasis Scientific Approach efektif meningkatkan hasil belajar pada aspek kognitif siswa kelas VII materi Ekosistem di SMP N I4 Yogyakarta T.A 20I4/2015.

Hasil belajar pada aspek kognitif siswa kelas eksperimen lebih tinggi daripada kelas kontrol dipengaruhi oleh beberapa faktor diantaranya, pengunaan model Guided Inquiry berbasis Scientific Approach pada kelas eksperimen merupakan hal baru yang dikenal oleh siswa disamping Model Direct Instruction yang sering diterapkan guru dalam pembelajaran IPA biologi di kelas. Faktor lainnya adalah keterlibatan siswa secara langsung dalam proses pembelajaran. Model Guided Inquiry berbasis Scientific Approach yang diterapkan di kelas, memfasilitasi siswa menemukan sendiri konsep materi ekosistem yang sedang dipelajari dengan pengamatan secara langsung pada objek kajian ekosistem di lingkungan nyata. Hal tersebut didukung oleh pernyataan Ristanto (2010: 3), bahwa lingkungan nyata akan memberikan rangsangan yang amat penting bagi siswa dalam mempelajari dan bereksplorasi menemukan sesuatu yang baru bagi dirinya. Menemukan sesuatu yang baru merupakan hal yang menyenangkan bagi siswa. Pembelajaran yang menyenangkan menyebabkan motivasi belajar siswa meningkat sehingga siswa tidak merasa bosan dalam mengikuti kegiatan belajar.

Pembelajaran ekosistem dengan menghadirkan objek kajian secara langsung dapat memberikan pengalaman belajar pada siswa sehingga konsep materi yang dipelajari akan mudah dipahami dan diingat siswa. Hal ini sesuai dengan penyataan Edgar Dale dalam penggolongan pengalaman belajar yang menyatakan bahwa, belajar yang baik adalah belajar melalui pengalaman langsung. Dalam belajar siswa tidak hanya mengamati, tetapi menghayati, terlibat langsung, dan bertanggung jawab terhadap proses dan hasilnya (Uno dan Muhammad, 20I I: I96).

Faktor lainnya adalah ketercakupan seluruh gaya belajar yang dimiliki siswa di kelas dapat terealisasi melalui Model Guided Inquiry berbasis Scientific Approach. Hal ini sesuai pendapat Jumardi (2013: 4) yang menyatakan bahwa, hasil belajar optimal akan diperoleh apabila beragam perbedaan seperti, kebiasaan, minat, dan gaya belajar pada siswa, diakomodasi oleh guru melalui pilihan pendekatan pembelajaran, dan kesesuaian materi ajar dengan gaya belajar siswa. Model dan pendekatan yang tepat serta ditunjang gaya belajar yang baik akan menciptakan pembelajaran yang lebih bermakna dan siswa mengerti relevansi apa yang dipelajari di sekolah dengan situasi kehidupan nyata.

Pada kelas kontrol, model pembelajaran yang digunakan berupa Direct Instruction. Dalam prosesnya, guru menyampaikan materi ekosistem secara verbal tanpa menghadirkan objek kajian nyata seperti pada kelas eksperimen. Hal tersebut berdampak pada hasil nilai posttest kelas kontrol lebih rendah daripada kelas eksperimen. Berdasarkan kerucut pengalaman Edgar Dale dalam Indriana (20II: 47), pengetahuan akan semakin abstrak apabila pesan hanya disampaikan melalui kata verbal. Akibatnya, siswa hanya akan memahami suatu pengetahuan dalam bentuk kata, tanpa mengerti dan memahami makna yang terkandung dalam pengetahuan tersebut. Dalam model Direct Instruction, gaya belajar siswa tidak tercakup secara keseluruhan, hanya siswa dengan gaya belajar audio dan visual saja yang mampu menerima materi pembelajaran secara optimal.

Siswa kelas eksperimen memiliki aktivitas pembelajaran yang tinggi dibandingkan siswa kelas kontrol karena keterlibatan langsung dalam pembelajaran. Hal tersebut dapat dilihat dari sintaks pembelajaran Model Guided Inquiry berbasis Scientific Approach yang diterapkan pada kelas eksperimen dimulai dari orientasi sampai validasi. Setiap sintaks dalam model pembelajaran tersebut memiliki kegiatan-kegiatan berbasis Scientific Approach, dimulai dari mengamati, menanya, mengumpulkan informasi, mengasosiasikan, dan mengkomunikasikan.

Pada sintaks pertama yaitu orientasi, siswa mulai diarahkan untuk fokus pada materi pelajaran yang akan disampaikan oleh guru. Pada tahapan ini guru menyampaikan tujuan pembelajaran sehingga siswa mengetahui kegiatan pembelajaran yang akan dilakukan pada saat itu, berusaha menggali pemahaman awal siswa, serta memotivasi siswa.

Pada sintaks kedua yaitu eksplorasi, terdapat kegiatan scientific approach berupa mengamati dan menanya. Kegiatan mengamati sangat bermanfaat bagi pemenuhan rasa ingin tahu siswa sehingga pembelajaran pun memiliki kebermaknaan yang tinggi. Pada tahapan ini, guru memberikan kesempatan kepada siswa untuk melakukan pengamatan pada objek kajian yang sedang dipelajari melalui kegiatan melihat, menyimak, mendengar, dan memperhatikan hal penting dari sebuah objek kajian (Machin, 20I4: 3I).

Sintaks ketiga yaitu pembentukan konsep. Dalam sintaks tersebut terdapat kegiatan Scientific Approach berupa mengumpulkan data. Kegiatan mengumpulkan data dilakukan untuk menggali dan mengumpulkan informasi dari berbagai sumber. Melalui kegiatan mengumpulkan data siswa belajar 
teliti, jujur, sopan, dan menghargai pendapat orang lain. Kegiatan mengumpulkan data dilaksanakan dengan pengamatan/observasi di lingkungan sekolah. Hal ini sesuai dengan ketentuan permendikbud Nomor 8I A Tahun 2013 yang menyatakan bahwa pada kegiatan mengumpulkan data, siswa dapat melaksanakan eksperimen, pengamatan /observasi, membaca sumber lain seperti buku teks, mengamati objek atau kejadian, aktivitas, dan wawancara dengan narasumber untuk memperoleh sejumlah informasi (Wardani, 20I4: 604).

Sintaks keempat yaitu aplikasi, terdapat kegiatan mengasosiasikan. Pada kegiatan ini siswa dituntut untuk menganalisis hasil pengamatan/observasi yang telah dilakukan sesuai dengan konsep materi dari bahan ajar yang ada serta membuat kesimpulan terhadap data yang diperoleh. Kegiatan mengasosiasikan bertujuan untuk membangun kemampun berpikir dan bersikap ilmiah. Data yang diperoleh dibuat klasifikasi, diolah, dan ditemukan hubungan-hubungan yang spesifik. Hasil kegiatan mengasosiasikan memungkinkan siswa berpikir kritis tingkat tinggi (higher order thinking skills) hingga berpikir metakognitif (Arnellis, 20I4: 27).

Sintaks kelima yaitu validasi. Dalam sintaks tersebut terdapat kegiatan mengkomunikasikan. Kegiatan tersebut dilakukan dengan cara mempresentasikan hasil belajar siswa di depan kelas kepada guru dan teman-teman lainnya. Kegiatan ini bermanfaat bagi pengembangan kemampuan berpikir sistematis, mengungkapkan pendapat dengan singkat dan jelas, dan mengembangkan kemampuan berbahasa yang baik dan benar (Rochintaniawati, 20I4: 3).

\section{Hasil Belajar Pada Aspek Afektif}

Berdasarkan uji hipotesis, didapatkan bahwa $\mathrm{H}_{0}$ ditolak, artinya Model Guided Inquiry berbasis Scientific Approach efektif meningkatkan hasil belajar pada aspek afektif siswa kelas VII materi Ekosistem di SMP N I4 Yogyakarta T.A 20I4/20I5.

Penggunaan Model Guided Inquiry berbasis Scientific Approach membuat hasil belajar pada aspek afektif kelas eksperimen lebih tinggi daripada kelas kontrol. Hal ini dikarenakan penggunaan model pembelajaran tersebut terkonsep secara aktif melibatkan siswa dalam berlangsungnya proses pembelajaran. Siswa mengikuti pelajaran dengan tertib sesuai arahan guru, bekerja sama dengan kelompoknya dengan baik saat observasi berlangsung, dan mampu menemukan sendiri fakta dan konsep yang sedang dipelajari melalui langkahlangkah ilmiah dengan tepat. Hal tersebut sesuai dengan pernyataan Putra (2013:35), bahwa siswa harus dilatih memecahkan masalah berdasarkan fakta, melalui pendekatan ilmiah. Dengan demikian siswa akan meningkat pengetahuannya melalui pengalaman empiris dalam proses menemukan konsep dan prinsip IPA sehingga akan terjadi perubahan sikap dan keterampilan ilmiah siswa seiring bertambah pengetahuannya.

Berbeda dengan kelas kontrol, penggunaan Model Direct Instruction kurang memberikan kesempatan kepada siswa untuk terlibat aktif dalam proses pembelajaran. Siswa hanya sebatas mendengarkan dan mencatat materi yang diberikan oleh guru. Menurut Bruner dalam (Winatapura, I993: I54-I55) selama kegiatan belajar berlangsung hendaknya siswa dibiarkan mencari atau menemukan sendiri makna segala sesuatu yang dipelajari. Siswa perlu diberikan kesempatan berperan sebagai pemecah masalah seperti yang dilakukan para ilmuwan, dengan cara tersebut diharapkan mereka mampu memahami konsep-konsep dalam bahasa mereka sendiri.

\section{Hasil Belajar Pada Aspek Psikomotor}

Berdasarkan uji hipotesis, didapatkan bahwa $\mathrm{H}_{0}$ ditolak, artinya Model Guided Inquiry berbasis Scientific Approach efektif meningkatkan hasil belajar pada aspek psikomotor siswa kelas VII materi Ekosistem di SMP N I4 Yogyakarta T.A 2014/2015.

Penggunaan Model Guided Inquiry berbasis scientific approach pada kelas eksperimen lebih tinggi daripada kelas kontrol. Hal tersebut menunjukkan siswa terampil dalam mengumpulkan data melalui kegiatan observasi/pengamatan, mengolah dan menganalisis data untuk kemudian dijadikan kesimpulan, serta mampu mengkomunikasikan secara langsung hasil yang telah didapat selama proses pembelajaran melalui presentasi di kelas. Kegiatan tersebut secara otomatis mengoptimalkan penggunaan indera yang dimiliki siswa sehingga siswa memperoleh pengalaman belajar yang bermakna. Masing-masing sintaks pada Model Guided Inquiry berbasis Scientific Approach membelajarkan siswa akan keterampilan proses sains (Wahyunningsih, 2012: 37).

Berbeda dengan kelas eksperimen, penggunaan Model Direct Instruction yang diterapkan di kelas kontrol menyebabkan aktivitas siswa sebatas mendengarkan penjelasan dari guru meskipun divariasi dengan diskusi. Namun, guru masih mendominasi pembelajaran sehingga belum melibatkan peran aktif siswa secara keseluruhan ketika kegiatan belajar berlangsung (Hapsari, 2012: 25). Selain itu, sintaks dalam Model Direct Instruction pada kelas kontrol kurang melatih keterampilan proses sains siswa dengan optimal (Wahyunningsih, 2012: 37) sehingga berdampak pada terbatasnya peranan siswa di kelas. 


\section{Simpulan}

Penerapan Model Guided Inquiry berbasis Scientific Approach menunjukkan bahwa terdapat perbedaan rata-rata yang signifikan pada hasil belajar IPA Biologi siswa SMP baik aspek kognitif, afektif, dan psikomotor. Hal itu dikarenakan model pembelajaran tersebut memfasilitasi siswa mengkonstruk pengetahuannya sendiri dan terlibat aktif dalam pembelajaran, sehingga hasil belajar siswa pun lebih bermakna.

Model Guided Inquiry berbasis Scientific Approach juga membelajarkan siswa untuk mengenal dan menerapkan metode ilmiah melalui langkah-langkah yang terperinci, dan bekerja sama dengan baik sehingga bertambah kecakapan afektif dan psikomotornya. Dengan demikian dapat disimpulkan bahwa hasil belajar IPA Biologi pada aspek kognitif, afektif, dan psikomotor signifikan rata-rata berbeda berdasarkan penerapan Model Guided Inquiry berbasis Scientific Approach.

\section{Daftar Pustaka}

Arnellis. 20I4. "Pendekatan Saintifik dalam Pembelajaran Matematika untuk Pembentukan Kemampuan Berpikir Matematis Tingkat Tinggi Siswa SMA”. Prosiding Seminar Nasional Pendidikan MIPA 2014 "Implementasi Pendekatan Saintifik dalam Pembelajaran MIPA Fakultas MIPA Universitas Negeri Padang.

Badan Standar Nasional Pendidikan. 2006. Panduan Penyusunan Kurikulum Tingkat Satuan Pendidikan. Jakarta: Depdiknas.

Daryanto. 2005. Evaluasi Pendidikan. Jakarta: Rineka Cipta.

Hamalik, Oemar. 20I0. Perencanaan Pengajaran Berdasarkan Pendekatan Sistem. Jakarta: Bumi Aksara.

Hapsari, Dewi Pertiwi, dkk. 20II. "Pengaruh Model Inkuiri Terbimbing dengan Diagram V (Vee) dalam Pembelajaran Biologi terhadap Kemampuan Berfikir Kritis dan Hasil Belajar Siswa”. Jurnal Pendidikan Biologi Vol 4, no. 3 hal. I6-28.

Indriana, Dina. 20II. Ragam Alat Bantu Media Pengajaran. Yogyakarta: Pustaka Pelajar.

Jumardi. 2013. "Pengaruh Pendekatan Pembelajaran dan Gaya Belajar terhadap Hasil Belajar Sejarah Siswa”. Jurnal Pendidikan Sejarah vol. 3 no I Januari-Juni 2014.

Lubis, Ahyani R, dan Binari Manurung. 2010. "Pengaruh Model dan Media Pembelajaran terhadap Hasil Belajar dan Retensi Siswa pada Pelajaran Biologi Di SMP Swasta Muhammadiyah Serbelawan”. Jurnal Pendidikan Biologi (DIKBIO) vol. I no. 3, hal. I46245.

Machin, A. 20I4. "Implementasi Pendekatan Saintifik, Penanaman Karakter dan Konservasi pada Pembelajaran Materi Pertumbuhan”. Jurnal Pendidikan IPA Indonesia. JPII 3 (I) hal. 28-35.

Marjan, Johari, I.B Putu Arnyana, dan I.G.A Nyoman Setiawan. 20I4. "Pengaruh pembelajaran Saintifik
Terhadap Hasil Belajar Biologi dan Keterampilan Proses Sains Siswa MA Mu'allimat NW Pancor Selong Kabupaten Lombok Timur Nusa Tenggara Barat”. E-Journal Program Pascasarjana Universitas Pendidikan Ganesha Program Studi IPA vol.4 Tahun 2014.

Mulyasa, E. 2006. Menjadi Guru Profesional: Menciptakan Pembelajaran yang Kreatif dan Menyenangkan. Bandung: PT. Rosda Karya.

Putra, Amali. 20I4. "Pembelajaran IPA Berbasis Pengamatan melalui Pendekatan Ilmiah di Sekolah Menengah Atas”. Jurnal Penelitian Pendidikan, vol. 5, no.I, hal. 3I-40.

Putri, Sagung, I Made Candiasa, dan I Ngurah Marheni. 20I4. "Pengaruh Implementasi Metode Inkuiri Terbimbing Berbasis Asesmen Kinerja terhadap Hasil Belajar IPA Ditinjau dari Sikap Ilmiah Siswa Kelas VIII SMP Negeri I Tegallalang”. Jurnal Penelitian dan Evaluasi pendidikan vol 4 (20I4).

Ristanto, R. H. 20I0. Pembelajaran Berbasis Inkuiri Terbimbing dengan Multimedia dan Lingkungan Rill Ditinjau dari Motivasi Berprestasi dan Kemampuan Awal. Tesis. Universitas Sebelas Maret Surakarta.

Rohani, A. 2004. Pengelolaan Pengajaran. Jakarta: Rineka Cipta.

Rochintaniawati, Diana. 20I4. "Pembelajaran IPA dengan Menggunakan Pendekatan Saintifik dalam Kurikulum 2013", Prosiding Seminar Nasional Pendidikan MIPA 2014 "Implementasi Pendekatan Saintifik dalam Pembelajaran MIPA”. Fakultas MIPA Universitas Negeri Padang.

Uno, Hamzah B dan Nurdin Mohamad. 20II. Belajar dengan Pendekatan PAILKEM. Jakarta: Bumi Aksara.

Varelas, M and Ford M. 2009. The scientific method and scientific inquiry: Tensions in teaching and learning. USA: Wiley Inter Science.

Wahyunningsih, Sri., Baskoro Adi Prayitno, dan Riezky Maya Probosa. 2012. Pengaruh Model Pembelajaran Inkuiri Terbimbing Terhadap Keterampilan Proses Sains Ditinjau Dari Kemampuan Akademik Siswa Sma Negeri 5 Surakarta. Jurnal Pendidikan Biologi Vol. 4 No. 3 Mei 2012 hal 33-43. http:/ / eprints.uns.ac.id/I2307/I/I4I4-3I45-ISM.pdf Diakes pada tanggal I Juli 2015 pukul I0.30 wib.

Winatapura. 1993. Strategi Belajar Mengajar IPA. Jakarta: Universitas Terbuka Depdikbud Jakarta.

Wardani, Eva R.S, Johanes Djoko, dan Sifak Indana. 2014.

"Analisis Kesesuaian Kegiatan Pembelajaran Pendekatan

Saintifik dengan Tujuan Pembelajaran Di SMAN

Mojokerto". Jurnal BioEdu. vol. 3, no. 3, hal. 60I-605. 